\begin{tabular}{|l|l|l||}
\hline \multicolumn{2}{|c|}{ PublisherInfo } \\
\hline \hline PublisherName & $:$ & BioMed Central \\
\hline \hline PublisherLocation & $:$ & London \\
\hline \hline PublisherImprintName & $:$ & BioMed Central \\
\hline \hline
\end{tabular}

\title{
Vasculature mapping
}

\begin{tabular}{|l|l|l||}
\hline \multicolumn{2}{|c||}{ ArticleInfo } \\
\hline \hline ArticleID & $:$ & 4400 \\
\hline \hline ArticleDOI & $:$ & 10.1186 /gb-spotlight-20020213-02 \\
\hline \hline ArticleCitationID & $:$ & spotlight-20020213-02 \\
\hline \hline ArticleSequenceNumber & $:$ & 66 \\
\hline \hline ArticleCategory & $:$ & Research news \\
\hline ArticleFirstPage & $:$ & 1 \\
\hline \hline ArticleLastPage & $:$ & 2 \\
\hline \hline & & RegistrationDate : 2002-2-13 \\
\hline ArticleHistory & $:$ & OnlineDate \\
\hline \hline ArticleCopyright & $:$ & BioMed Central Ltd2002-13 \\
\hline \hline ArticleGrants & $:$ & \\
\hline \hline ArticleContext & $:$ & 130593311 \\
\hline \hline
\end{tabular}




\section{Jonathan B Weitzman}

Email: jonathanweitzman@hotmail.com

A few years ago Renata Pasqualini and Erkki Ruoslahti developed an in vivoselection method to identify peptides that target specific vascular beds following intravenous administration of random peptide phage-display libraries in mice. In the February issue of Nature Medicine, Pasqualini's group at the MD Anderson Cancer Center in Texas report the application of 'in vivo phage display' to characterize the human vasculature (Nature Medicine 2002, 8:121-127). They injected a large-scale, random peptide library into a terminally ill patient and collected tissue samples 15 minutes post-infusion. They recovered phage from different organs and carried out a high-throughput analysis of over 4,000 phage inserts. Comparison of the selected tripeptide motif frequencies revealed a non-random, tissue-specific distribution. They then used a phage-overlay histological assay to validate peptide sequences specific for prostate or skin tissues. This study represents a first step towards a well-characterized map of the heterogeneity within the human vasculatuure, opening up the possibilities for targeted drug delivery strategies.

\section{References}

1. Organ targeting in vivo using phage display peptide libraries.

2. Nature Medicine, [http://medicine.nature.com]

3. MD Anderson Cancer Center, [http://www.mdanderson.org] 